\title{
RADIOCARBON DATING OF HOLOCENE SEDIMENTS: FLOOD EVENTS AND EVOLUTION OF THE LABE (ELBE) RIVER IN CENTRAL BOHEMIA (CZECH REPUBLIC)
}

\author{
PAVEL JÍLEK, ${ }^{1}$ JAROSLAVA MELKOVÁ, ${ }^{1}$ ELIŠKA RŮŽIČKOVÁ, ${ }^{2}$ JAN ŠILAR ${ }^{1}$ and \\ ANTONÍN ZEMAN ${ }^{2}$
}

\begin{abstract}
We studied the structure and development of the Holocene floodplain of the Labe (Elbe) River by radiocarbon dating sections of the upper and middle courses of the river. We focused on geomorphological and sedimentological conditions, mineralogy and the chemical composition of sediments. We established the stratigraphy of the Holocene deposits of the floodplain. The results of our investigation of fluvial sediments imply that several abrupt changes in temperature and precipitation occurred during the Holocene. These changes led to intervals of hydrological disequilibrium, which caused the formation of two Holocene terraces and a contemporaneous floodplain. The lower terrace was flooded and covered with sediments upon which the recent floodplain formed. During the Holocene, there were four periods during which large tree trunks were deposited in the fluvial sediments, indicating periods of extensive flooding. The supposition that these events were of more global scale is supported by the results of investigations made on the Holocene floodplains of other regions.
\end{abstract}

\section{INTRODUCTION}

We studied the structure and development of the Holocene floodplain of the Labe River in selected sections of the upper and middle courses of the river in the territory of the Czech Republic (Fig. 1). We focused on the sedimentology and stratigraphy of the Holocene deposits of this floodplain and determined the sedimentary chronology in archaeological studies using radiocarbon dating. We found that the terrace structure of the Holocene floodplain formed by repeated erosion and aggradation. At intervals during the periods of sedimentation, tree trunks were deposited, indicating periods of increased flooding. Human settlement also affected the evolution of the Holocene floodplain. Wood samples were taken from carbonized oak trunks that were found in fluvial sediments of the Labe River under the water level.

\section{METHODS}

\section{Radiocarbon Dating}

We dated wood samples in the Radiocarbon Laboratory of the Department of Hydrogeology and Engineering Geology, Charles University, Prague. The dating methods used in this laboratory were described previously (Šilar and Tykva 1991). The samples received the standard acid-base-acid (ABA) treatment and were ${ }^{14} \mathrm{C}$-measured by $\mathrm{CO}_{2}$ proportional counting. Table 1 summarizes the measurements of 23 samples collected over a period of several years.

Results are reported in ${ }^{14} \mathrm{C}$ years before present (BP) with 1- $\sigma$ standard deviation and calculated using the convention of Stuiver and Polach (1977). The ${ }^{14} \mathrm{C}$ ages were also dendrochronologically corrected using the CALIB 3.0 program (Stuiver and Reimer 1993). The standard deviations of the corrected ages result from those of the ${ }^{14} \mathrm{C}$ ages and of the calibration curve. The corrected ages are reported in 1- and 2- $\sigma$ standard deviations.

\footnotetext{
${ }^{1}$ Department of Hydrogeology and Engineering Geology, Faculty of Science, Charles University, Albertov 6, 12843 Praha 2, Czech Republic

${ }^{2}$ Geological Institute of the Academy of Sciences of the Czech Republic, Rozvojova 135, 16500 Praha 6, Czech Republic
} 


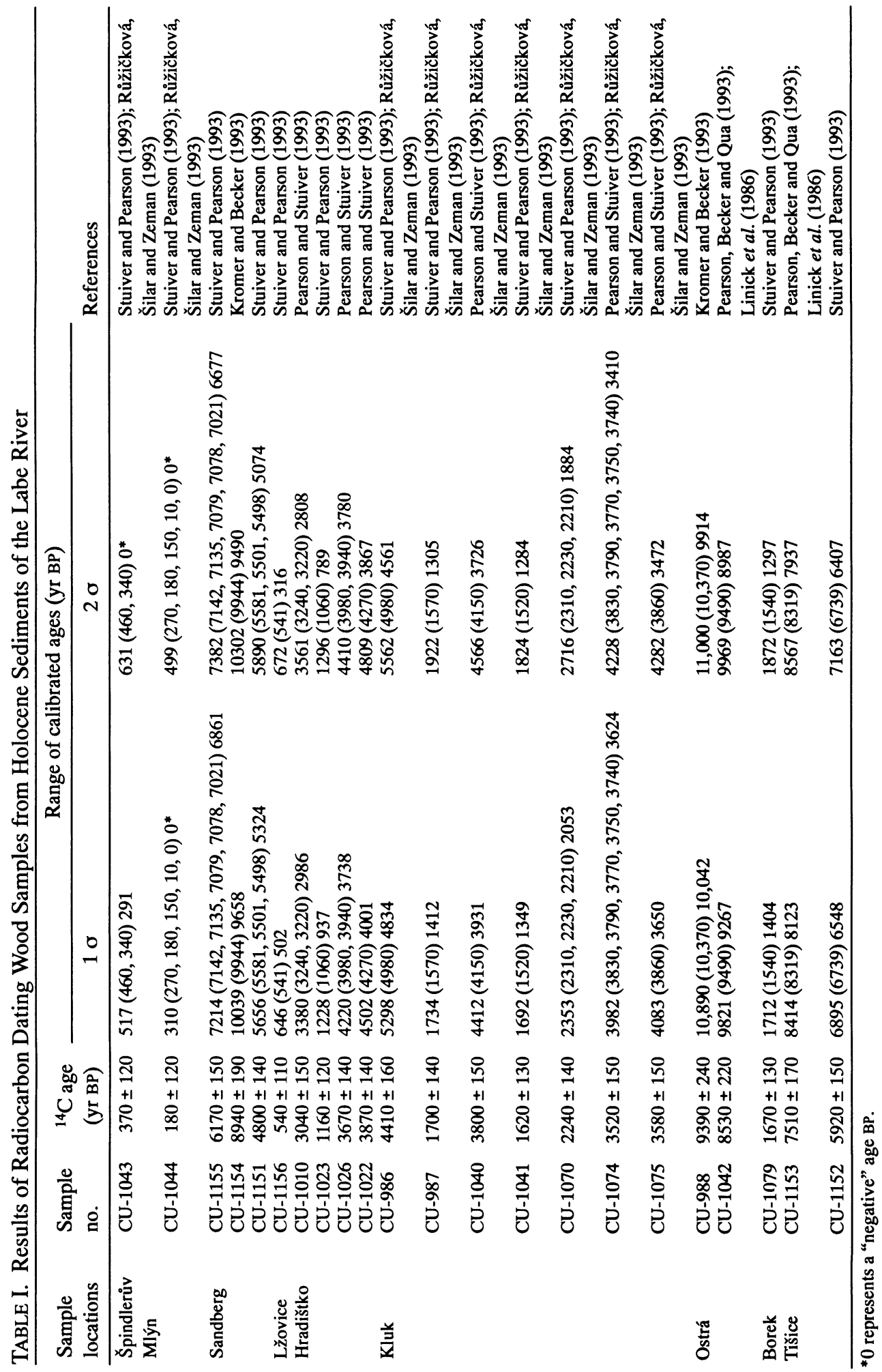




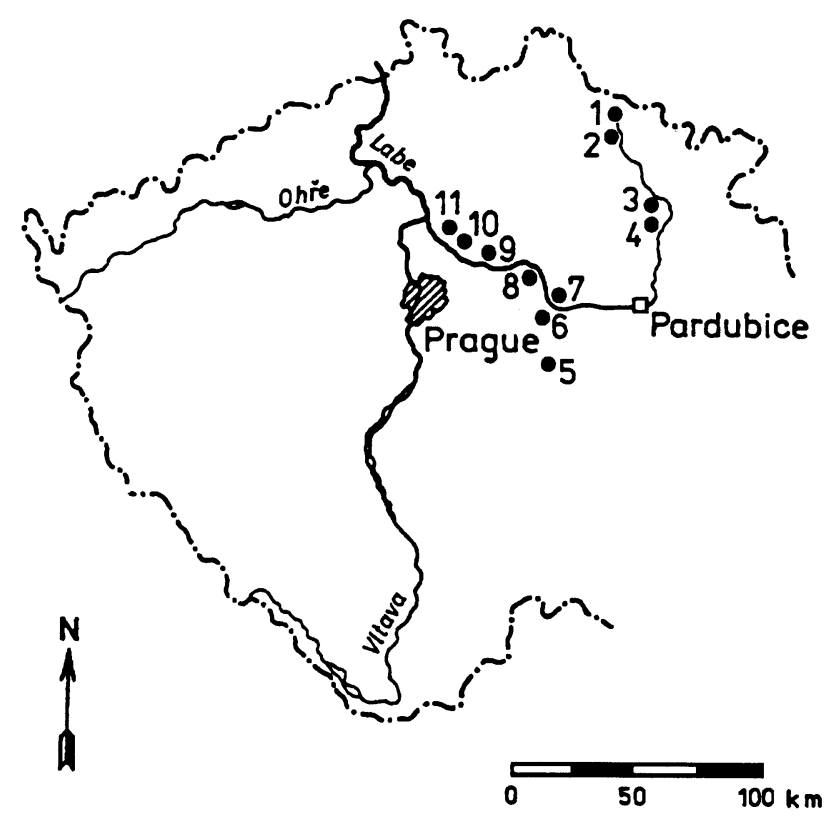

Fig. 1. Site locations: 1. Śpindlerův Mlýn; 2. Vrchlabí; 3. Hostinné; 4. Debrné; 5. Bylany; 6. Sandberg and Lžovice; 7. Hradištko; 8. Kluk; 9. Ostrá; 10. Borek; 11. Tißice

\section{Sedimentological Research}

Three natural levels can be distinguished in the Holocene floodplain of the upper and middle courses of the Labe River: two floodplain terraces (higher and lower) and the recent floodplain (Fig. 2). The two floodplain terraces are not consistently developed along the whole course because of local conditions (e.g., there is an antecedent valley at Kuks). The three levels provide evidence for the existence of three periods when the river reached a graded profile, i.e., the sediments were neither eroding nor accumulating. Changes were usually sudden and resulted in a considerable increase of sedimentary discharge.

The recent floodplain level developed during sweeping floods in the Little Ice Age, at their highest frequency during the Middle Ages, connected with cooling and increased precipitation during cold climatic fluctuations. The higher floodplain terrace lies $4 \mathrm{~m}$ above the present river level and is a remnant of an early Holocene floodplain. It consists of early Holocene fluvial gravel and sand, and wind-blown sands. Remnants of river meanders are preserved on its surface. Underlying Pleistocene fluvial sandy gravels, characterized by pine woods occur in cores taken from these meanders.

The surface of this higher floodplain terrace is covered with layers of sand and silt. At Ostrá, we discovered a 40-cm-thick silt intercalation, but we have not determined its origin; it may represent weathered pyroclastic material. Findings of high concentrations of $\mathrm{Nb}$ (13-15 ppm), Y (28-46 ppm) and $\mathrm{Zr}(121-267 \mathrm{ppm})$ seem to support this assumption. These elements and their contents suggest low-alkali to alkali volcanism. Underlying Cretaceous marlstones ( $\mathrm{Nb}<7 \mathrm{ppm}, \mathrm{Y} 9 \mathrm{ppm}, \mathrm{Zr} 92$ $\mathrm{ppm}$ ), and Quaternary fluvial sediments ( $\mathrm{Nb}<7 \mathrm{ppm}, \mathrm{Y}<7 \mathrm{ppm}, \mathrm{Zr} 21 \mathrm{ppm}$ ) show considerably lower concentrations of these elements. 


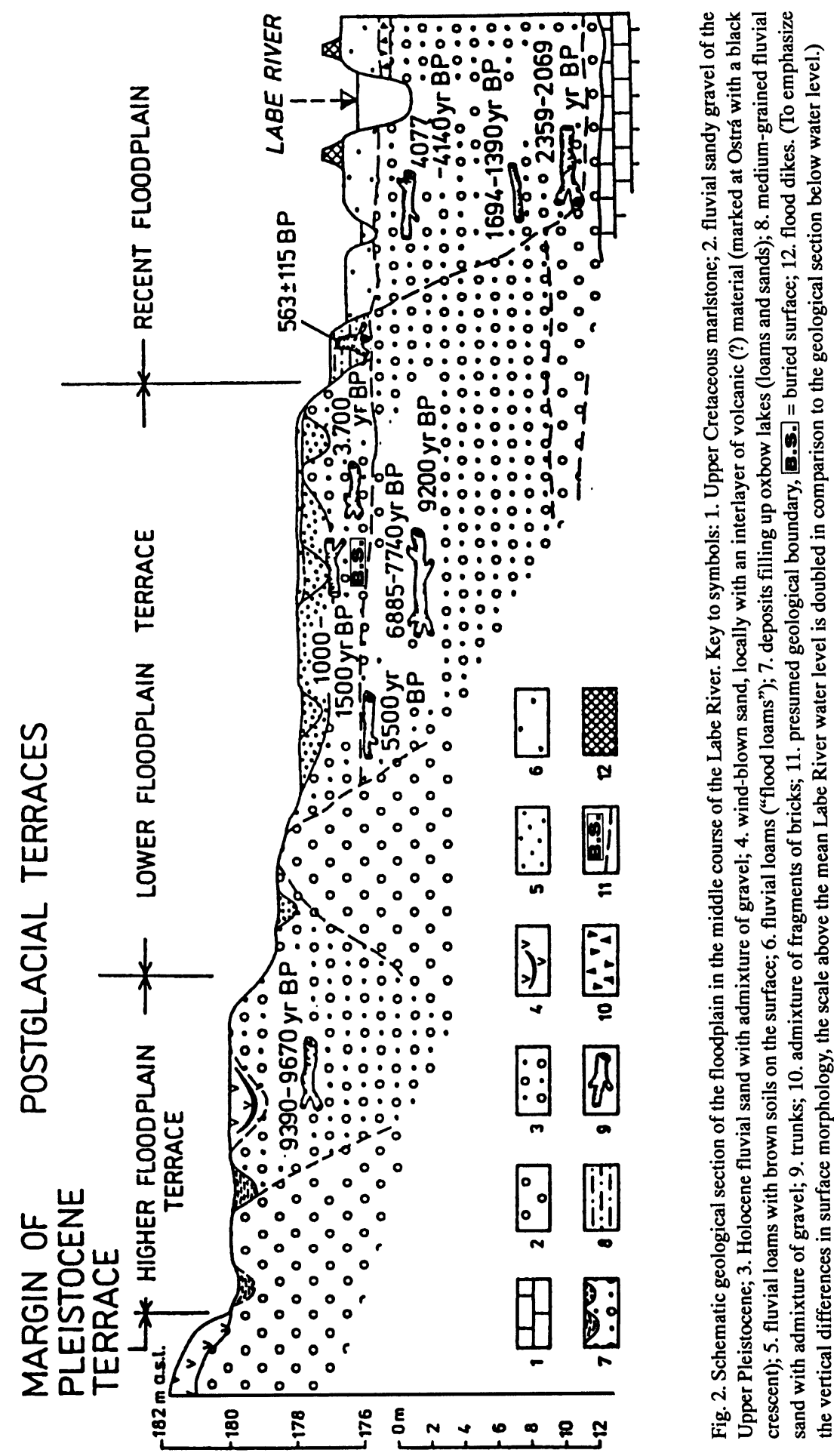


The lower Labe River floodplain terrace represents a remnant terrace from the end of the archaeological "fortified settlement" age. The surface of this terrace lies $2.5-3.0 \mathrm{~m}$ above the present river level. It consists of fluvial sands with an admixture of gravel and fluvial sandy loams that cover the majority of this terrace and that fill depressions of abandoned meanders. This level was studied at Sandberg and Hradištko (Fig. 1). Archaeological findings are known on the remnant terrace at Hradištko.

The recent floodplain is the narrowest, compared to the others, reaching only $0.2-0.25$ the width of the lower floodplain terrace. This annually flooded area is covered with fluvial "flood loams" and numerous oxbow lakes connected with the river. The present Labe River valley has been made navigable mostly at the level of the recent floodplain by straightening the river course, thereby cutting off numerous meanders from the river system. The new riverbed can be described as a navigable canal with perfectly paved river banks. The origin of this recent floodplain is linked with an abrupt climate change at the onset of the Little Ice Age.

\section{RESULTS}

We summarize below the main stages of the development of the Holocene Labe River floodplain (the chronology is indicated in calibrated years BP for the period prior to $\mathrm{AD} 0$ as usual in Quaternary geology, and in calibrated years $\mathrm{AD}$ for the subsequent period, as usual in archaeology).

10,000-9500 cal BP

Erosion of the Pleistocene sandy gravels from the last glacial; accumulation of sediments of the upper floodplain level; occurrence of oak forests on the surface of the floodplain.

$9500-9000$ cal BP

Successively: sedimentation of a layer containing tree trunks (see Table 1, Ostrá samples); isolated occurrence of Pleistocene fluvial sediments in meander cores, occasionally with Mesolithic settlements; eolian activity; deposition of volcanogenic material; wind-blown sands.

$\sim 8000$ cal BP

Disruption of the graded profile; fluvial erosion, formation of the upper floodplain terrace as a morphological level; formation of the base of deposits of the lower floodplain terrace.

$7700-6900 \mathrm{cal}_{B P}$

Second layer with trunks; redeposition of older sediments including subfossil trunks from the upper floodplain terrace and deposition of younger trunks, accumulation of fluvial sands and gravels of the lower floodplain terrace.

$\sim 5500$ cal BP

Third layer with trunks; the river system reaches an equilibrium and begins to meander; deposition of organic material in oxbow lakes; onset of Neolithic settlement continuing to the Bronze Age (Dreslerová 1994); trunks with traces of cutting at the Kluk site (Fig. 1).

$\sim 3700$ cal BP

Fourth layer with trunks; destruction of river equilibrium; sudden renewal of sedimentation of gravels and sands; fluvial sands and gravels overlie the previous surface. 
$3500-3200$ cal BP

Equilibrium is re-established; further river meandering; deposition of fluvial loams; brown soils develop on the surface of the floodplain in areas covered with floodplain forest.

$\sim A D 0$

A new wave of settlement in the first centuries (the Roman period), and in the early Middle Ages.

$A D 1150$

Destruction of equilibrium; floods; settlements are abandoned again during the early Middle Ages; $c a$. 2-m erosion in some parts of the floodplain; the floodplain forest reappears.

$A D 1250$

Extensive floods and aggradation; floodplain forest partially buried by overbank deposits.

$A D$ 1550-1700

Extensive floods caused by considerable cooling and humidification of climate; formation of the space for the recent floodplain; redeposition; sedimentation.

$A D$ 1800-1900

Deposition of fluvial loams and sands; the river reaches equilibrium and meanders; in the late 19th century, the floodplain is resettled; large-scale construction on the surface of the recent floodplain; regulation of the river flow; bank protection; construction of locks and weirs; opening of new large sand pits.

\section{CONCLUSION}

Our investigation of the Holocene fluvial sediments of the Labe River suggests that several abrupt changes in temperature and precipitation occurred during the Holocene. These changes caused periods of hydrological disequilibrium that resulted in the formation of two Holocene terraces, and are marked by four intervals of tree-trunk deposition in the fluvial sediments. In central Europe, these intervals represent climatic catastrophes, and they may correlate with global events, as suggested by studies of Holocene floodplains in other regions (Schirmer 1980, 1983).

Our present knowledge thus indicates that the current Labe River valley is the result of abrupt, irregularly repeated climatic events that occurred over the past 10,000 yr. Will similar climatic changes take place in the future? It seems likely, but our present knowledge about the processes causing these changes does not allow us to predict them. In particular, we do not know how to separate the recent anthropogenic impacts from the climate-controlled hydrological changes.

\section{ACKNOWLEDGMENTS}

Research on the Holocene floodplain of the Labe River was part of an integrated multidisciplinary project, "The Paleoclimatic Record in Upper Pleistocene and Holocene Sediments in the Labe River Valley and Prognosis of the Climate". This project was financed by the Grant Agency of the Academy of Sciences of the Czech Republic. 


\section{REFERENCES}

Kromer, B. and Becker, B. 1993 German oak and pine ${ }^{14} \mathrm{C}$ calibration, $7200-9400$ BC. In Stuiver, M., Long, A. and Kra, R.S., eds., Calibration 1993. Radiocarbon 35(1): 125-135.

Linick, T. W., Long, A., Damon, P. E. and Ferguson, C. W. 1986 High-precision radiocarbon dating of bristlecone pine from 6554 to 5350 BC. In Stuiver, M. and $\mathrm{Kra}, \mathrm{R}$. S., eds., Proceedings of the 12th International ${ }^{14} \mathrm{C}$ Conference. Radiocarbon 28(2B): 943-953.

Pearson, G. W., Becker, B. and Qua, F. 1993 High-precision ${ }^{14} \mathrm{C}$ measurement of German and Irish oaks to show the natural ${ }^{14} \mathrm{C}$ variations from 7890 to $5000 \mathrm{BC}$. In Stuiver, M., Long, A. and Kra, R. S., eds., Calibration 1993. Radiocarbon 35(1): 93-104.

Pearson, G. W. and Stuiver, M. 1993 High-precision bidecadal calibration of the radiocarbon time scale, 500-2500 BC. In Stuiver, M., Long, A. and Kra, R. S., eds., Calibration 1993. Radiocarbon 35(1): 25-34

Rủžičková, E., Šilar, J. and Zeman, A. 1993 Flood plain of the Labe River in the Little Ice Age. In Rủžičková, E., Zeman, A. and Mirecki, J., eds., Application of Direct and Indirect Data for the Reconstruction of Climate During the Last Two Millenia. Prague, Geological Institute of the Academy of Sciences of the Czech Republic: 63-70.

Schirmer, W., ed. 1980 Exkursionsführer zum Symposium Franken, Holozäne Talentwicklung. In Meth- oden und Ergebnisse. Proceedings of Symposium Franken 25.-30.8.1980 in Lichtenfels und Staffelstein (Oberfranken). Düsseldorf, Deutsche Forschungsgemeinschaft: $210 \mathrm{p}$.

1983 Die Talentwicklung an Main und Regnitz seit dem Hochwürm. Geologisches Jahrbuch A71: 11-43.

Silar, J. and Tykva, R. 1991 Charles University, Prague radiocarbon measurements I. Radiocarbon 33(1): 69 78.

Šilar, J. and Zeman, A. 1989 Results of radiocarbon dating of Holocene fluviatile sediments in northeastern Bohemia. Věstník Ústředního Ústavu Geologického, 64(1): 39-42.

1990 Radiocarbon dating of Holocene fluviatile sediments in north-eastern Bohemia. In Proceedings of the 5th Working Meeting on Isotopes in Nature. Leipzig, Central Institute of Isotope and Radiation Research: 165-169.

Stuiver, M. and Pearson, G. W. 1993 High-precision bidecadal calibration of the radiocarbon time scale, $\mathrm{AD}$ 1950-500 BC and 2500-6000 BC. In Stuiver, M., Long, A. and Kra, R. S., eds., Calibration 1993. Radiocarbon 35(1): 1-24.

Stuiver, M. and Reimer, P. 1993 Extended ${ }^{14} \mathrm{C}$ data base and revised CALIB 3.0 ${ }^{14} \mathrm{C}$ age calibration program. In Stuiver, M., Long, A. and Kra, R. S., eds., Calibration 1993. Radiocarbon 35(1): 215-230. 